\title{
Comparative cytogenetics in Cyclopogon (Orchidaceae)
}

\author{
Mauro Grabiele ${ }^{1 *}$, Juan C. Cerutti ${ }^{1}$, Diego H. HojsgaArd ${ }^{2}$, Rubén D. Almada ${ }^{3}$, \\ Julio R. Daviñ A ${ }^{1} \&$ Ana I. Honfi ${ }^{1}$ \\ ${ }^{1}$ Instituto de Biología Suptropical (IBS-CONICET), Facultad de Ciencias Exactas, Químicas y Naturales, Universidad \\ Nacional de Misiones, Félix de Azara 1552, 3300 Posadas, Argentina; e-mail: maurograbiele@conicet.gov.ar \\ ${ }^{2}$ Department of Systematic and Evolutionary Botany, Faculty Centre of Biodiversity, University of Vienna, Rennweg 14, \\ A-1030 Vienna, Austria \\ ${ }^{3}$ Instituto de Investigaciones Agropecuarias (INIA Rayentué), Avda. Salamanca s/n, Km 105 ruta 5 sur, sector Los \\ Choapinos, C.C. 13, Rengo, Chile
}

\begin{abstract}
A cytotaxonomical description of Cyclopogon (Spiranthinae, Orchidaceae) is carried out through a deep karyotype analysis of four species from NE Argentina. Distinctive karyotype parameters concerning the chromosomes number, morphology, size and symmetry and the genome size associate to each taxon. Cyclopogon calophyllus $(2 n=2 x=28$; $18 m+10 s m), C$. congestus $(2 n=2 x=32 ; 26 m+6 s m), C$. elatus $(2 n=2 x=28 ; 18 m+10$ sm $)$ and $C$. oliganthus $(2 n=4 x=64 ; 40 m+24 s m)$ possess symmetrical karyotypes $\left(i\right.$-mean $\left.=40.01-42.84 ; A_{1}=0.24-032 ; r>2=0.06-0.29\right)$ and excluding $C$. congestus $\left(A_{2}=0.26 ; R=2.62\right)$ unimodality is the rule $\left(A_{2}=0.12-0.20 ; R=1.73-1.92\right)$. Diploid taxa show a terminal macrosatellite in the $m$ pair no. 2 (large arm) and share a comparable mean chromosome length (ca. $2.75 \mu \mathrm{m})$ and genome size (ca. $40 \mu \mathrm{m}$ ), superior to the tetraploid C. oliganthus (ca. 2 and $32 \mu \mathrm{m}$, respectively). The novel data added to preceding cytological, morphological and molecular approaches involving Cyclopogon and those related taxa of Spiranthinae largely based on $x=23$ support the hypothesis that the unusual $2 n$ and the karyotype morphology of Cyclopogon is an evolutionary advance within Spiranthinae with a basic reduction to $x=14$ or 16 by chromosome fusions. A polyploid-dysploid series added to dibasic hybridization explain the extant $2 n$ diversity though a paleopolyploid series on $x=7-8$ is also possible.
\end{abstract}

Key words: chromosome evolution; dibasic hybridization; karyotype analysis; Sipranthinae

\section{Introduction}

Cyclopogon C. Presl is a widely distributed American genus of spiranthoid orchids, comprising ca. 55 to 70 terrestrial and rarely epiphytic species, with a main diversity center in Bolivia, Brazil, Ecuador and Peru though reaching to México, Guatemala, Cuba and Argentina (Correa 1955; Felix \& Guerra 2005). In Argentina 8 to 9 species of Cyclopogon are recorded limited to the northern, eastern and central regions of the country, usually showing intra and interspecific diversity regarding to the colour of the leaves and the plant morphology (Correa 1996; Johnson 2001; Insaurralde \& Radins 2007).

Cyclopogon is one of the main genera in the subtribe Spiranthinae which is important for horticulture, however there is little information available in the literature. Karyological data in Cyclopogon is scarce with only eight species from N Argentina, Brazil and Peru chromosomally studied, displaying a wide diversity in chromosome numbers and ploidy levels ranging from $2 n$ $=28$ to 66 (Martinez 1981, 1985; Tanaka \& Maekawa 1983; Felix \& Guerra 2005; Daviña et al. 2009). Meiotic analysis carried out in five taxa of this genus showing $2 n=28,32$ or 64 chromosomes found a regular behaviour and $n=14,16$ or 32 bivalents exclusively, respectively (Martinez 1981; Cerutti et al. 2004; Felix \& Guerra 2005; Grabiele et al. 2011a). Nevertheless, a deep karyotipic characterization of Cyclopogon is still missing with some contributions made by Martinez (1981, 1985), Tanaka \& Maekawa (1983), Felix \& Guerra (2005) and Daviña et al. (2009) which a priori reveal primary structural differences respecting the related taxa in Spiranthinae largely based on $x=23$ (Grabiele et al. 2010, 2011b). However, questions of the origins of the observed chromosome numbers diversity, the fundamental karyotipic differences and the basic chromosome number of Cyclopogon remain unsolved.

The present work encompass the first extensive cytotaxonomical description of Cyclopogon, carrying out a deep karyotype analysis of four species from NE Argentina displaying diverse chromosome numbers and ploidy levels, that support in the understanding of the chromosome evolution in this distinctive genus of spiranthoid orchids.

\section{Material and methods}

Four species of Cyclopogon from NE Argentina were chromosomally characterized. Voucher specimens were deposited 
Table 1. Chromosome numbers $(2 n)$, locality and geographical coordinates, voucher specimens and herbaria of Cyclopogon species studied.

Cyclopogon calophyllus (Barb. Rodr.) Barb. Rodr., $2 n=28$. Misiones Province, Capital Department, Posadas, at the coast of Paraná river, $27^{\circ} 21^{\prime} \mathrm{S}, 56^{\circ} 00^{\prime} \mathrm{W}$, Cerutti 74 (MNES); Corrientes Province, Ituzaingó Department, Garapé, at the coast of Paraná river, $27^{\circ} 36^{\prime} \mathrm{S}, 56^{\circ} 22^{\prime} \mathrm{W}$, Cerutti 28 (MNES)

Cyclopogon congestus (Vell.) Hoehne, $2 n=32$. Misiones Province, San Ignacio Department, at the coast of Yabebiry stream, $27^{\circ} 18^{\prime} \mathrm{S}, 55^{\circ} 34^{\prime} \mathrm{W}$, Almada \& Cerutti 150 (MNES); Misiones Province, Cainguás Department, Aristóbulo del Valle, Parque Provincial Salto Encantado del Valle del Cuñá Pirú, $27^{\circ} 05^{\prime} \mathrm{S}, 54^{\circ} 57^{\prime} \mathrm{W}$, Hojsgaard 192 (MNES); Misiones Province, San Pedro Department, Parque Provincial Moconá, at the coast of Uruguay river, $27^{\circ} 09^{\prime} \mathrm{S}, 53^{\circ} 54^{\prime} \mathrm{W}$, Hojsgaard 306 (MNES)

Cyclopogon elatus (Sw.) Schltr., $2 n=28$. Misiones Province, Capital Department, Garupá, at the coast of Garupá stream, Cerutti, Grabiele \& Hojsgaard 72 (MNES); Misiones Province, Apóstoles Department, Apóstoles, at the coast of Chimiray stream, $27^{\circ} 54^{\prime} \mathrm{S}, 55^{\circ} 49^{\prime} \mathrm{W}$, Hojsgaard, Cerutti \& Grabiele 341 (MNES); Corrientes Province, Capital Department, Corrientes, at the coast of Paraná river, $27^{\circ} 27^{\prime} \mathrm{S}, 58^{\circ} 48^{\prime} \mathrm{W}$, Lirussi 708 (MNES)

Cyclopogon oliganthus (Hoehne) Hoehne \& Schltr., $2 n=64$. Misiones Province, Apóstoles Department, Apóstoles, at the coast of Chimiray stream, $27^{\circ} 54^{\prime} \mathrm{S}, 55^{\circ} 49^{\prime} \mathrm{W}$, Hojsgaard, Cerutti \& Grabiele 339 (MNES); Misiones Province, Capital Department, Miguel Lanús, close to swamp of Zaimán stream, $27^{\circ} 26^{\prime} \mathrm{S}, 55^{\circ} 53^{\prime} \mathrm{W}$, Cerutti, Grabiele \& Hojsgaard 71 (MNES, CTES)

at the herbarium of the Universidad Nacional de Misiones (MNES) and some duplicates at the Instituto de Botanica del Nordeste herbarium (CTES).

Mitotic studies were performed in root tips pretreated with saturated 1-bromonaphthalene for $2-3 \mathrm{hrs}$ at room temperature, fixed in absolute ethanol : glacial acetic acid (3:1) for $12 \mathrm{hrs}$ at $4{ }^{\circ} \mathrm{C}$ and stained according to the Feulgen technique. The meristems were macerated in a drop of $2 \%$ aceto-orcein and then squashed. Permanent slides were made using euparal as a mounting medium. Slides were analyzed with a Leica DMLS optical photomicroscope, photographs were taken with Imagelink HQ 25 ASA Kodak film, and negatives were digitalized with a Genius ColorPageHR8 scanner.

The karyotype description and nomenclature followed Levan et al. (1964): the chromosomes were arranged in groups according to the position of the centromere (metacentric, $m$; submetacentric, $s m$; subtelocentric, $s t$ ) estimated through the centromeric index (i) and in order of decreasing size in each class. Satellites were classified according to Battaglia (1955). At least ten best metaphases were selected for making idiograms. The lengths of chromosome arms and satellites were measured on drawings made with a camera lucida $(\times 2600)$. Karyotype symmetry was estimated using the $A_{1}$ and $A_{2}$ asymmetry indexes of Romero Zarco (1986), as well as the $R$ and $r>2$ asymmetry indexes to determine the categories of Stebbins (1971).

\section{Results and discussion}

Four species of Cyclopogon representing half of the taxa of the genus in NE Argentina (Correa 1996) were karyotypically characterized in depth for the first time: $C y$ clopogon calophyllus (Barb. Rodr.) Barb. Rodr., Cyclopogon congestus (Vell.) Hoehne, Cyclopogon elatus (Sw.) Schltr. and Cyclopogon oliganthus (Hoehne) Hoehne and Schltr. Chromosome numbers (2n), locality and geographical coordinates, voucher specimens and herbaria of species studied are summarized in Table 1. In addition, Table 2 sums up the karyotype parameters of studied taxa and Table 3 provides a review of the cytogenetic data obtained in Cyclopogon to date. Selected photomicrographs of the chromosomes and the idiograms of the four species are shown in Figs 1a-d and $2 \mathrm{a}-\mathrm{d}$, respectively. The supplemental data summarizes the quantitative parameters of chromosomes of studied taxa.

Cyclopogon calophyllus is a rare terrestrial orchid of the understory of subtropical forests of Argentina, where it is limited to Jujuy, Misiones and Corrientes Provinces, SE Brazil and Bolivia (Correa 1996; Johnson 2001; Insaurralde \& Radins 2007). It is a diploid taxon with $2 n=28$ chromosomes. In agreement, Daviña et al. (2009) reported the same number and Grabiele et al. (2011a) found a regular meiotic behavior and $n=$ 14 bivalents for these Argentinian accessions of C. calophyllus. The karyotype, composed by $18 m+10 \mathrm{sm}$ chromosomes, is unimodal ( $\left.A_{2}=0.20 ; R=1.92\right)$ and symmetrical $\left(A_{1}=0.32 ; r>2=0.29 ; i=40.01\right)$ and belongs to Stebbins' category $2 \mathrm{~A}$; the pair no. $2(\mathrm{~m})$ carries a terminal macrosatellite in the large arm. The chromosome length ranges from $2.20 \mu \mathrm{m}(\mathrm{m})$ to $4.23 \mu \mathrm{m}(\mathrm{sm})$ with a mean of $3.05 \mu \mathrm{m}$; the total chromosome length is $85.25 \mu \mathrm{m}$ and $42.65 \mu \mathrm{m}$ the genome size.

Cyclopogon congestus is present at the northern regions of Argentina, in the subtropical forests of Jujuy, Salta, Tucuman and Misiones Provinces, and extends into neighboring countries such as Brazil, Paraguay and Uruguay (Correa 1996; Johnson 2001); it possesses a particular habit, which is commonly terrestrial but often epiphytic, growing at medium height on rocks and tree trunks (Johnson 2001). It is a diploid taxon showing $2 n=32$ chromosomes. In agreement, Daviña et al. (2009) reported the same number for these Argentinian accessions of $C$. congestus. Other counts in plants from Misiones constantly established $2 n=32$ additionally to $n=16$ bivalents [Martinez 1981; as Beadlea congesta (Vell.) Garay, Martinez 1984] with the exception of a unique cytotype of $2 n=28$ chromosomes (Martinez 1981; see below). Also, a cytotype of $2 n=36$ was reported by Tanaka \& Maekawa (1983) from Peruvian Andes mountains accessions of $C$. congestus. The karyotype, composed by $26 m+6 s m$ chromosomes, is slightly bimodal $\left(A_{2}=0.26 ; R=2.62\right)$ and symmetrical $\left(A_{1}=0.24 ; r>2=0.06 ; i=42.84\right)$ and belongs to Stebbins' category $2 \mathrm{~B}$; the pair no. $2(\mathrm{~m})$ carries a terminal macrosatellite in the large arm. The chromosome length ranges from $1.48 \mu \mathrm{m}(m)$ to $3.87 \mu \mathrm{m}(m)$ 


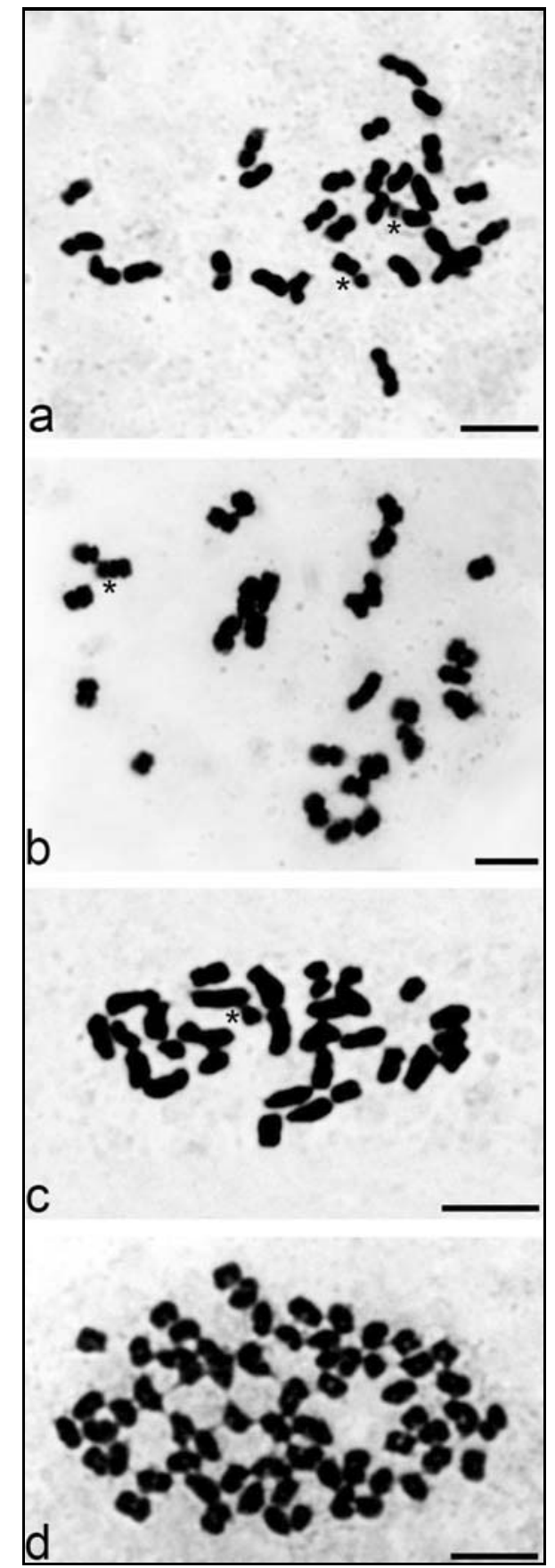

Fig. 1. Somatic chromosomes of Cyclopogon species studied. a C. calophyllus, $2 n=28 ; \mathrm{b}-C$. elatus, $2 n=28 ; \mathrm{c}-C$. congestus, $2 n=32 ; \mathrm{d}-C$. oliganthus, $2 n=64$. The asteriks point out the macrosatellites. Bar $=5 \mu \mathrm{m}$.

with a mean of $2.41 \mu \mathrm{m}$; the total chromosome length is $77.06 \mu \mathrm{m}$ and $38.53 \mu \mathrm{m}$ the genome size. The coexisting terrestrial and epiphytic accessions of $C$. congestus studied here did not show any morphological and karyotypic differences, so it is fair to consider them as a single taxon. In agreement with our results, Martinez (1981, 1985) found a comparable karyotype morphology for the cytotype with $2 n=32$ chromosomes. Moreover, the cytotype $2 n=36$ (Tanaka \& Maekawa 1983) displayed a bimodal and symmetrical karyotype, with two large $m$ and thirty-four median to small size $m, s m$,

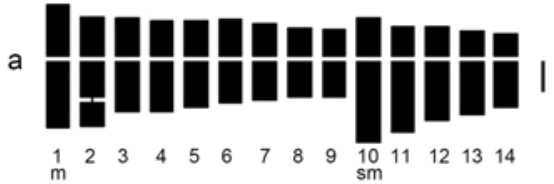

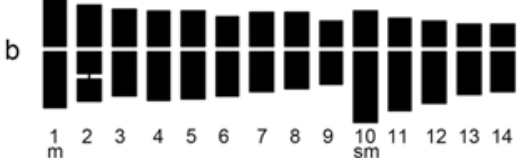

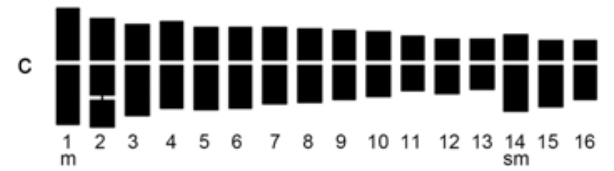

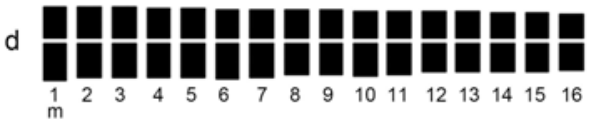

\section{HAHAH

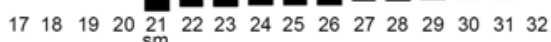

Fig. 2. Idiograms of Cyclopogon species studied. a - C. calophyllus, $18 m+10 \mathrm{sm} ; \mathrm{b}-C$. elatus, $18 m+10 \mathrm{sm} ; \mathrm{c}-C$. congestus, $26 m+6 s m ; \mathrm{d}-C$. oliganthus, $40 m+24 s m$. Bar $=1 \mu \mathrm{m}$.

and st chromosomes varying from 5 to $1 \mu \mathrm{m}$ in length, which is hard to be related to the typical cytotype of C. congestus.

Cyclopogon elatus is a widely distributed polymorphic orchid of varied habit that occupies the understory of tropical and subtropical forests from North and Central America to Uruguay and northern, eastern and central regions of Argentina (Correa 1955, 1996; Johnson 2001; Tropicos.org 2012). It is a diploid species displaying $2 n=28$ chromosomes. In agreement, Daviña et al. (2009) reported the same number and Cerutti et al. (2004) found a regular meiotic behavior and $n=14$ bivalents for these Argentinian accessions of $C$. elatus. Other counts in this taxon found $n=14$ bivalents and $2 n=28$ for NE Argentina plants, in addition to $2 n=$ 30 and $2 n=45$ (45?, see below) for Brazilian and Misiones materials, respectively (Martinez 1981) added to $2 n=28$ from NE Brazil populations (Felix \& Guerra $2005)$. The karyotype, composed by $18 m+10 \mathrm{sm}$ chromosomes, is unimodal ( $A_{2}=0.17 ; R=1.82$ ) and symmetrical $\left(A_{1}=0.28 ; \mathrm{r}>2=0.21 ; i=41.22\right)$ and belongs to Stebbins' category $2 \mathrm{~A}$; the pair no. $2(\mathrm{~m})$ carries a terminal macrosatellite in the large arm. The chromosome length ranges from $2.06 \mu \mathrm{m}(m)$ to $3.75 \mu \mathrm{m}$ $(\mathrm{sm})$ with a mean of $2.81 \mu \mathrm{m}$; the total chromosome length is $78.61 \mu \mathrm{m}$ and $39.31 \mu \mathrm{m}$ the genome size. In agreement with our results, Martinez (1981) and Felix \& Guerra (2005) found a comparable karyotype morphology for the cytotype with $2 n=28$ chromosomes of C. elatus. According to Correa (1955) and Johnson (2001), in the natural environment $C$. elatus is morpho- 
Table 2. Karyotype parameters of Cyclopogon species studied.

\begin{tabular}{|c|c|c|c|c|}
\hline & C. calophyllus & C. elatus & C. congestus & C. oliganthus \\
\hline$x$ & 14 & 14 & 16 & 32 \\
\hline $2 n$ & 28 & 28 & 32 & 64 \\
\hline Ploidy level & $2 \mathrm{x}$ & $2 \mathrm{x}$ & $2 \mathrm{x}$ & $4 \mathrm{x}$ \\
\hline Karyotype formula & $18 m+10 s m$ & $18 m+10 s m$ & $26 m+6 s m$ & $40 m+24 s m$ \\
\hline TCL & $85.25 \mu \mathrm{m}$ & $78.61 \mu \mathrm{m}$ & $77.06 \mu \mathrm{m}$ & $126.69 \mu \mathrm{m}$ \\
\hline Genome size & $42.65 \mu \mathrm{m}$ & $39.31 \mu \mathrm{m}$ & $38.53 \mu \mathrm{m}$ & $31.68 \mu \mathrm{m}$ \\
\hline$c$ & $3.05 \mu \mathrm{m}$ & $2.81 \mu \mathrm{m}$ & $2.41 \mu \mathrm{m}$ & $1.98 \mu \mathrm{m}$ \\
\hline C-max & $4.23 \mu \mathrm{m}-\mathrm{sm}$ & $3.75 \mu \mathrm{m}-\mathrm{sm}$ & $3.87 \mu \mathrm{m}-m$ & $2.38 \mu \mathrm{m}-\mathrm{m}, \mathrm{sm}$ \\
\hline $\mathrm{c}-\mathrm{min}$ & $2.20 \mu \mathrm{m}-m$ & $2.06 \mu \mathrm{m}-m$ & $1.48 \mu \mathrm{m}-m$ & $1.38 \mu \mathrm{m}-m$ \\
\hline$i$ & 40.01 & 41.22 & 42.84 & 41.43 \\
\hline$A_{1}$ & 0.32 & 0.28 & 0.24 & 0.28 \\
\hline$A_{2}$ & 0.20 & 0.17 & 0.26 & 0.12 \\
\hline $\mathrm{R}$ & 1.92 & 1.82 & 2.62 & 1.73 \\
\hline$r>2$ & 0.29 & 0.21 & 0.06 & 0.16 \\
\hline Stebbins' category & $2 \mathrm{~A}$ & $2 \mathrm{~A}$ & $2 \mathrm{~B}$ & $2 \mathrm{~A}$ \\
\hline
\end{tabular}

$x$, basic chromosome number; $2 n$, sporophytic chromosome number; TCL, total chromosome length; $c$, mean chromosome length; C-max, largest chromosome length; c-min, shortest chromosome length; i, mean centromeric index; $A_{1}$, intrachromosomal asymmetry index; $A_{2}$, interchromosomal asymmetry index; $R$, ratio of largest/shortest chromosome pairs; $r>2$, proportion of chromosome pairs with arm ratio $>2$.

logically close to $C$. calophyllus and $C$. congestus. So the unusual cytotype of $2 n=28$ chromosomes reported for an accession of $C$. congestus from Misiones (Martinez 1981) could probably be related to a misleading taxonomical determination. Furthermore, Martinez (1981) found that the cytotype $2 n=30$ with small size chromosomes of $C$. elatus from Brazil is morphologically close to $C$. congestus and suggested a dibasic hybridization as the cause. Regarding the cytotype $2 n=45$ of $C$. elatus reported by Martinez (1981), just $2 n=44$ chromosomes can be counted from the metaphase plate displayed in the original article. By the way, this accession has small size chromosomes and it is barely less unimodal than the common $2 n=28$ cytotype of $C$. elatus. The high and unusual chromosome number led Martinez (1981) to propose a probable origin of that cytotype throughout dibasic hybridization added to poliploidization.

Cyclopogon oliganthus is a terrestrial taxon of marked peat habit that lives in Argentina, restricted to the subtropical forests of Salta, Corrientes and Misiones Provinces, and Brazil (Correa 1996; Tropicos.org 2012); it is small sized and often coexists with other species of the genus in the forests bordering rivers and streams. It is a tetraploid taxon with $2 n=64$ chromosomes. In accordance, Daviña et al. (2009) reported the same number and Grabiele et al. (2011a) found a regular meiotic behaviour and $n=32$ bivalents for these Argentinian accessions of $C$. oliganthus. The karyotype, composed by $40 m+24 s m$ chromosomes, is unimodal $\left(A_{2}=0.12\right.$; $R=1.73)$ and symmetrical $\left(A_{1}=0.28 ; r>2=0.16 ; i=\right.$ $41.43)$ and belongs to Stebbins' category $2 \mathrm{~A}$. The chromosome length ranges from $1.38 \mu \mathrm{m}(m)$ to $2.38 \mu \mathrm{m}$ $(m, s m)$ with a mean of $1.98 \mu \mathrm{m}$; the total chromosome length is $126.69 \mu \mathrm{m}$ and $31.68 \mu \mathrm{m}$ the genome size. The arrangement of the chromosomes in the haploid karyotype suggest that $C$. oliganthus is autotetraploid in origin however this is not entirely convincing since chromosome rearrangement can occur during poliploidization events (Soltis \& Soltis 1999).

The obtained karyotype parameters allow a sim- ple distinction of the four taxa of Cyclopogon analyzed here, even when $C$. calophyllus and $C$. elatus share the same karyotype formula (Table 2) and for this reason acquire a great cytotaxonomical value, enhanced by their similarities at the morphological level. Diploid taxa share a similar mean chromosome length (ca. $2.75 \mu \mathrm{m}$ ) and genome size (ca. $40 \mu \mathrm{m}$ ), both of which are higher than those of the tetraploid $C$. oliganthus (ca. $2 \mu \mathrm{m}$ and ca. $32 \mu \mathrm{m}$, respectively), as is expected for polyploid taxa. Regarding to the position of the centromere all the taxa possess symmetrical karyotypes as evidenced by their $A_{1}, i$ and $r>2$ intrachromosomal asymmetry indexes values. In addition, considering the relative chromosomes size the whole taxa but $C$. congestus have unimodal karyotypes as supported by the low values of their $A_{2}$ and $R$ interchromosomal asymmetry indexes.

On the other hand, the cytotaxonomical value of the obtained karyotype parameters exceeds Cyclopogon. According to Johnson (2001), in vegetative state and lacking the particular striped leaves, C. calophyllus can be confused with Mesadenella cuspidata (Lindl.) Garay, however the later has a distinct karyotype morphology $(2 n=46 ; 38 m+8 s m$; Grabiele et al. 2011b).

Karyological data in Cyclopogon is scarce with only eight out of fifty-five to seventy species from N Argentina, Brazil and Peru chromosomally studied, displaying a wide diversity in chromosome numbers and ploidy levels, $2 n=28,30,32,36,45,56,64,66$ (Table 3 ; this work). Meiotic analysis carried out in five taxa of this genus showing $2 n=28,32$ or 64 chromosomes found a regular behaviour and $n=14,16$ or 32 bivalents exclusively, respectively (Table 3 ). Moreover, an extensive review of Cyclopogon cytogenetics revealed the presence of symmetrical karyotypes, in which most of the chromosomes are $m$ to $s m$; in addition, small to median size chromosomes never exceeding $5 \mu \mathrm{m}$ in length are common together with unimodal karyotypes, but bimodality due to a few large chromosome pairs is also present (Table 3, this work) without reaching the 
Table 3. Review of the cytogenetic data obtained in Cyclopogon to date.

\begin{tabular}{|c|c|c|c|c|}
\hline Taxa & $n$ & $2 n$ & Locality and References & Observations* \\
\hline $\begin{array}{l}\text { C. argyrifolius Barb. } \\
\text { Rodr. }\end{array}$ & & 32 & Brasil. Martinez (1981) & Small size chromosomes \\
\hline $\begin{array}{l}\text { C. calophyllus (Barb. } \\
\text { Rodr.) Barb. Rodr. }\end{array}$ & $14 \mathrm{II}$ & 28 & $\begin{array}{l}\text { Argentina. Daviña et al. } \\
(2009) \text {, Grabiele et al. (2011a) }\end{array}$ & Regular meiotic behaviour. Median size chromosomes \\
\hline $\begin{array}{l}\text { C. chloroleucus Barb. } \\
\text { Rodr. }\end{array}$ & & 36 & Brasil. Felix \& Guerra (2005) & $\begin{array}{l}4 \text { large } m \text { carrying macrosatellites at their large arms, as in this } \\
\text { work accessions of } C \text {. calophyllus, C. congestus, and } C \text {. elatus, and } \\
32 \text { median size } m \text { to sm chromosomes. Symmetrical and slightly } \\
\text { bimodal karyotype }\end{array}$ \\
\hline \multirow[t]{4}{*}{$\begin{array}{l}\text { C. congestus (Vell.) } \\
\text { Hoehne }\end{array}$} & & 32 & $\begin{array}{l}\text { Argentina. Daviña et al. } \\
(2009)\end{array}$ & Median size chromosomes \\
\hline & $16 \mathrm{II}$ & 32 & $\begin{array}{l}\text { Argentina. Martinez (1981, } \\
\text { 1985) }\end{array}$ & $\begin{array}{l}\text { Regular meiotic behaviour. Small size chromosomes and bimodal } \\
\text { karyotype. Similar karyotype morphology to this work accessions } \\
\text { of C. congestus }\end{array}$ \\
\hline & & 28 & Argentina Martinez (1981) & Small size chromosomes \\
\hline & & 36 & $\begin{array}{l}\text { Peru. Tanaka \& Maekawa } \\
(1983)\end{array}$ & $\begin{array}{l}2 \text { large } m \text { and } 34 \text { median to small size } m, s m \text {, and } s t \text { chromosomes } \\
\text { varying from } 5-1 \mu \mathrm{m} \text {. Symmetrical and bimodal karyotype }\end{array}$ \\
\hline \multirow[t]{5}{*}{ C. elatus (Sw.) Schltr. } & $14 \mathrm{II}$ & 28 & $\begin{array}{l}\text { Argentina. Cerutti et al. } \\
(2004) \text {, Daviña et al. (2009) }\end{array}$ & Regular meiotic behaviour. Median size chromosomes. \\
\hline & $14 \mathrm{II}$ & 28 & Argentina. Martinez (1981) & $\begin{array}{l}\text { Small size } m \text { to } s m \text { chromosomes and unimodal karyotype. Similar } \\
\text { karyotype morphology to this work accessions of } C \text {. elatus }\end{array}$ \\
\hline & & 30 & Brasil. Martinez (1981) & Small size chromosomes \\
\hline & & 45 & Argentina. Martinez (1981) & $\begin{array}{l}\text { Small size chromosomes. Barely less unimodal than } 2 n=28 \text { cyto- } \\
\text { type of } C \text {. elatus }\end{array}$ \\
\hline & & 28 & Brasil. Felix \& Guerra (2005) & $\begin{array}{l}\text { Median size } m \text { to } s m \text { chromosomes and unimodal karyotype. Simi- } \\
\text { lar karyotype morphology to this work accessions of } C \text {. elatus }\end{array}$ \\
\hline C. elegans Hoehne & & $\begin{array}{l}56 \\
66\end{array}$ & $\begin{array}{l}\text { Argentina. Martinez (1981) } \\
\text { Brasil. Martinez (1981) }\end{array}$ & $\begin{array}{l}\text { Small size chromosomes } \\
\text { Small size chromosomes. Bimodal karyotype }\end{array}$ \\
\hline $\begin{array}{l}\text { C. multiflorus Schltr. } \\
\text { C. oliganthus } \\
\text { (Hoehne) Hoehne \& } \\
\text { Schltr. }\end{array}$ & $\begin{array}{l}14 \text { II } \\
32 \text { II }\end{array}$ & 28 & $\begin{array}{l}\text { Brasil. Felix \& Guerra (2005) } \\
\text { Argentina. Daviña et al. } \\
\text { (2009), Grabiele et al. (2011a) }\end{array}$ & $\begin{array}{l}\text { Regular meiotic behaviour. } 28 \mathrm{~m} \text { to } \mathrm{sm} \text { chromosomes } \\
\text { Regular meiotic behaviour. Median size chromosomes }\end{array}$ \\
\hline
\end{tabular}

$n$, gametic chromosome number; $2 n$, sporophytic chromosome number; II, bivalents; * Made from the original authority and our own review of the original article

extreme values than in related genera of spiranthoid orchids (Grabiele et al. 2010, 2011b).

Subtribe Spiranthinae includes ca. 400 species of which less than fifty of them were chromosomally studied to date showing a preponderance of $x=23$ and bimodal karyotypes with one or a few chromosome pairs quite larger than the rest (Martinez 1981, 1985; Felix \& Guerra 2005; Daviña et al. 2009; Grabiele et al. 2010, 2011b). Morphological and molecular approaches to circumscribe Spiranthinae supported the inclusion of $C y$ clopogon as a sister group of Pelexia Poit. ex Lindl. and Sarcoglottis C. Presl within the Pelexia clade, which in turn is sister to the Stenorrhynchos clade, that embraces Eltroplectris Raf., Mesadenella Pabst and Gary, Sacoila Raf. and Skeptrostachys Garay (Salazar et al. 2003, 2009; Figueroa et al. 2008). Pelexia clade and Stenorrhynchos clade are also well sustained by defined cytological markers and all the taxa but Cyclopogon commonly display $2 n=46$ and bimodal karyotypes with lower mean chromosome lengths than taxa with $2 n=28$ or 32 cytotypes of Cyclopogon (ca. $1.85 \mu \mathrm{m}$ vs. ca. $2.75 \mu \mathrm{m}$, respectively) however sharing a comparable genome size of ca. $40 \mu \mathrm{m}$ (Daviña et al. 2009; Grabiele et al. 2010, 2011b, this work). The combined evidence supports the hypothesis that the unusual chromosome numbers and the karyotype morphology of $C y$ - clopogon is an evolutionary advance within Spiranthinae, and also suggests a number reduction in this genus from $x=23$ by means of chromosome fusions. In this regard, chromosome fusion/fission mechanisms could still be active in extant taxa of Cyclopogon, since the karyotype of $C$. congestus $(2 n=32,26 m+6 s m)$ mainly differentiate from those of $C$. callophylus and C. elatus $(2 n=28,18 m+10 s m)$ for the presence of four additional small $m$ chromosomes (nos. 10-13) in the former instead of the typical large $\mathrm{sm}$ chromosomes nos. 10 and 11 in the latter taxa. However, a strong number reduction from $x=23$ without implying chromosome fusions is achievable for the singular Eltroplectris schelechteriana (Porto \& Brade) Pabst $(2 n=$ 26; Daviña et al. 2009) which lost 20 of the 44 typical small $m$ to $s m$ chromosomes of Stenorrhynchos clade taxa, emphasizing the multisomic structure related to polyploidy in the cluster, but preserves the characteristic bimodal karyotype organization of the group due to the exceptionally large pair that carries the NOR (Grabiele et al. 2010, 2011b). Other related case of number reduction from $x=23$ apparently not involving chromosome fusions concerns Stygmatosema polyaden (Vell.) Garay placed in Cyclopogoninae Szlach. (Szlachetko 1995; more or less Pelexia clade) with $2 n=40$ small chromosomes ranging from 
$1 \mu \mathrm{m}$ to $2.5 \mu \mathrm{m}$ and unimodal karyotype (Daviña et al. 2009).

In any case, the chromosomes number diversity found in Cyclopogon could be explained in terms of a paleopolyploid series derived from $x=23$ and based primarily on $x=7(n=14,21,28,35)$ or $x=8(n=$ $16,24,32)$ added to dysploidy at each level and dibasic hybridization events. On the other hand, a similar proposal of a polyploid-dysploid series but based primarily on $x=14$ or $x=16$ together with dibasic hybridization is a possible alternative, even more taken into account the comparable genome sizes between those Cyclopogon displaying $2 n=28$ or 32 cytotypes and the related taxa with $x=23$ of Spiranthinae. In this regard, the exclusive diploidized meiotic behaviour found in the genus supports equally to both propositions.

\section{Acknowledgements}

This study was supported by the Consejo Nacional de Investigaciones Científicas y Técnicas de Argentina (CONICET) from which M.G. is career member and J.C.C. received a postdoctoral fellowship. We also acknowledge to the reviewers whose helpful comments improved the manuscript.

\section{References}

Battaglia E. 1955. Chromosome morphology and terminology. Caryologia 8: 179-187.

Cerutti J.C., Grabiele M., Hojsgaard D.H., Honfi A.I., Daviña J.R., Insaurralde I.S. \& Almada R.D. 2004. Citotaxomomía en especies de Cyclopogon Presl (Orchidaceae). Actas II Congreso Argentino de Orquideología y Conservación, pp. 1-7.

Correa M.N. 1955. Las orquídeas argentinas de la tribu Polychondreae Schlechter, subtribu Spiranthinae Pfitzer. Darwiniana 11: $24-88$.

Correa M.N. 1996. Orchidaceae. In: Zuloaga F.O. \& Morrone O. (eds), Catálogo de las Plantas Vasculares de la República Argentina I Pteridophyta, Gymnospermae y Angiospermae (Monocotyledoneae). Monogr. Syst. Bot. Mo. Bot. Gard.60: $1-323$.

Daviña J.R., Grabiele M., Cerutti J.C., Hojsgaard D.H., Almada R.D., Insaurralde I.S. \& Honfi A.I. 2009. Chromosome studies in Orchidaceae from Argentina. Genet. Mol. Biol. 32: 811821.
Felix L.P. \& Guerra M. 2005. Basic chromosome numbers of terrestrial orchids. Plant Syst. Evol. 254: 131-148.

Figueroa C., Salazar G.A., Zavaleta H.A. \& Engleman E.M. 2008. Root character evolution and systematics in Cranichidinae, Prescottiinae and Spiranthinae (Orchidaceae, Cranichideae). Ann. Bot. 101: 509-520.

Grabiele M., Honfi A.I., Cerutti J.C., Fernandez V., Franco D. \& Daviña J.R. 2010. Cytogenetic analysis in the terrestrial orchid Sacoila argentina (Griseb) Garay from Paraguay. Bot. Stud. 51: 337-342.

Grabiele M., Cerutti J.C., Hojsgaard D.H., Almada R.D., Daviña J.R. \& Honfi A.I. 2011a. Chromosome studies in Orchidaceae from Argentina, III. In: Marhold K. (ed), IAPT/IOPB chromosome data 12. Taxon 60: 4-5, E24-27.

Grabiele M., Cerutti J.C., Hojsgaard D.H., Almada R.D., Daviña J.R. \& Honfi A.I. 2011b. Chromosome studies in Orchidaceae from Argentina, II. In: Marhold K. (ed.), IAPT/IOPB chromosome data 11. Taxon 60: 1220-1221, E4-E6.

Insaurralde I.S. \& Radins J.A. 2007. Misiones Orquídeas - Orchids. 1st edn Buenos Aires Golden Company, Buenos Aires, $192 \mathrm{pp}$.

Johnson A.E. 2001. Las Orquídeas del Parque Nacional Iguazú. LOLA, Buenos Aires, 296 pp.

Levan A., Fredga K.L. \& Sandberg A.A. 1964. Nomenclature for centromeric position on chromosomes. Hereditas 52: 201-220.

Martínez A.J. 1981. Notas citotaxonomicas sobre el género $C y$ clopogon Presl. Parodiana 1: 139-148.

Martínez A.J. 1985. The chromosomes of Orchids VIII Spiranthinae and Cranichidinae. Kew Bull. 40: 139-147.

Romero Zarco C. 1986. A new method for estimating karyotype asymmetry. Taxon 3: 531-536.

Salazar G.A., Chase M.W., Arenas M.S. \& Ingrouille M. 2003. Phylogenetics of Cranichideae with emphasis on Spiranthinae (Orchidaceae, Orchidoideae): Evidence from plastid and nuclear DNA Sequences. Am. J. Bot. 90: 777-795.

Salazar G.A., Cabrera L.I., Madrinán S. \& Chase M.W. 2009. Phylogenetic relationships of Cranichidinae and Prescottiinae (Orchidaceae, Cranichideae) inferred from plastid and nuclear DNA sequences. Ann. Bot. 104: 403-416.

Soltis D.E. \& Soltis P.S. 1999. Polyploidy: recurrent formation and genome evolution. Trends Ecol. Evol. 14: 348-352.

Stebbins G.L. 1971. Chromosomal evolution in higher plants. Reading: Addison-Wesley, New York, 216 pp.

Szlachetko D. 1995. Sistema Orchidalium. Fragm. Florist. Geobot. 3: $1-152$.

Tanaka R. \& Maekawa F. 1983. Observation of chromosome in some orchid species from Peru and Mexico. Ann. Tsukuba Bot. Gard. 2: 33-45.

Tropicosorg. 2012. Missouri Botanical Garden. http:// wwwtropicosorg/Name/ (accessed 02.05.2012).

Received May 13, 2012 Accepted July 19, 2012

\section{Supplemental data}

Quantitative parameters of chromosomes of Cyclopogon species studied.

\begin{tabular}{|c|c|c|c|c|c|c|}
\hline Pair & $s-\mu \mathrm{m}(\mathrm{SE})$ & $l-\mu \mathrm{m}(\mathrm{SE})$ & $c-\mu \mathrm{m}(\mathrm{SE})$ & $i$ & RL\% & Type \\
\hline \multicolumn{7}{|c|}{ Cyclopogon calophyllus } \\
\hline 1 & $1.82(0.06)$ & $2.33(0.05)$ & $4.15(0.08)$ & 43.8 & 9.7 & $\mathrm{~m}$ \\
\hline 2 & $1.47(0.05)$ & $1.95(0.02)$ & $3.41(0.10)$ & 43.0 & 8.0 & m-sat \\
\hline 3 & $1.41(0.03)$ & $1.84(0.06)$ & $3.25(0.01)$ & 43.3 & 7.6 & $\mathrm{~m}$ \\
\hline 4 & $1.25(0.03)$ & $1.78(0.03)$ & $3.03(0.02)$ & 41.3 & 7.1 & $\mathrm{~m}$ \\
\hline 5 & $1.26(0.06)$ & $1.61(0.02)$ & $2.87(0.01)$ & 43.9 & 6.7 & $\mathrm{~m}$ \\
\hline 6 & $1.31(0.03)$ & $1.43(0.01)$ & $2.74(0.01)$ & 47.8 & 6.4 & $\mathrm{~m}$ \\
\hline 7 & $1.17(0.04)$ & $1.35(0.05)$ & $2.51(0.03)$ & 46.4 & 5.9 & $\mathrm{~m}$ \\
\hline 8 & $1.08(0.05)$ & $1.26(0.08)$ & $2.34(0.04)$ & 46.2 & 5.5 & $\mathrm{~m}$ \\
\hline 9 & $0.96(0.03)$ & $1.24(0.06)$ & $2.20(0.02)$ & 43.7 & 5.2 & $\mathrm{~m}$ \\
\hline 10 & $1.24(0.03)$ & $2.99(0.03)$ & $4.23(0.01)$ & 29.3 & 9.9 & $\mathrm{sm}$ \\
\hline 11 & $1.15(0.14)$ & $2.38(0.19)$ & $3.53(0.01)$ & 32.7 & 8.3 & $\mathrm{sm}$ \\
\hline
\end{tabular}




\begin{tabular}{|c|c|c|c|c|c|c|}
\hline Pair & $s-\mu \mathrm{m}(\mathrm{SE})$ & $l-\mu \mathrm{m}(\mathrm{SE})$ & $c-\mu \mathrm{m}(\mathrm{SE})$ & $i$ & $\mathrm{RL} \%$ & Type \\
\hline 12 & $1.06(0.10)$ & $2.09(0.15)$ & $3.16(0.03)$ & 33.7 & 7.4 & $\mathrm{sm}$ \\
\hline 13 & $0.91(0.07)$ & $1.89(0.14)$ & $2.80(0.02)$ & 32.6 & 6.6 & sm \\
\hline 14 & $0.79(0.05)$ & $1.61(0.22)$ & $2.40(0.01)$ & 33.0 & 5.6 & sm \\
\hline \multicolumn{7}{|c|}{ Cyclopogon elatus } \\
\hline 1 & $1.75(0.01)$ & $1.94(0.01)$ & $3.69(0.01)$ & 47.4 & 9.4 & $\mathrm{~m}$ \\
\hline 2 & $1.50(0.01)$ & $1.56(0.04)$ & $3.06(0.04)$ & 49.0 & 7.8 & m-sat \\
\hline 3 & $1.38(0.04)$ & $1.56(0.04)$ & $2.94(0.01)$ & 46.9 & 7.5 & $\mathrm{~m}$ \\
\hline 4 & $1.22(0.02)$ & $1.72(0.02)$ & $2.94(0.01)$ & 41.5 & 7.5 & $\mathrm{~m}$ \\
\hline 5 & $1.25(0.09)$ & $1.63(0.09)$ & $2.88(0.01)$ & 43.5 & 7.3 & $\mathrm{~m}$ \\
\hline 6 & $1.06(0.04)$ & $1.56(0.04)$ & $2.63(0.01)$ & 40.5 & 6.7 & $\mathrm{~m}$ \\
\hline 7 & $1.19(0.04)$ & $1.41(0.07)$ & $2.59(0.02)$ & 45.8 & 6.6 & $\mathrm{~m}$ \\
\hline 8 & $1.19(0.04)$ & $1.31(0.04)$ & $2.50(0.01)$ & 47.5 & 6.4 & $\mathrm{~m}$ \\
\hline 9 & $0.91(0.02)$ & $1.16(0.15)$ & $2.06(0.13)$ & 43.9 & 5.2 & $\mathrm{~m}$ \\
\hline 10 & $1.25(0.09)$ & $2.50(0.01)$ & $3.75(0.09)$ & 33.3 & 9.5 & sm \\
\hline 11 & $1.03(0.02)$ & $2.06(0.04)$ & $3.09(0.07)$ & 33.3 & 7.9 & $\mathrm{sm}$ \\
\hline 12 & $0.89(0.01)$ & $1.81(0.01)$ & $2.70(0.04)$ & 33.1 & 6.9 & $\mathrm{sm}$ \\
\hline 13 & $0.81(0.04)$ & $1.50(0.01)$ & $2.31(0.01)$ & 35.1 & 5.9 & $\mathrm{sm}$ \\
\hline 14 & $0.78(0.02)$ & $1.38(0.01)$ & $2.16(0.02)$ & 36.2 & 5.5 & $\mathrm{sm}$ \\
\hline \multicolumn{7}{|c|}{ Cyclopogon congestus } \\
\hline 1 & $1.80(0.07)$ & $2.07(0.10)$ & $3.87(0.01)$ & 46.6 & 10.0 & $\mathrm{~m}$ \\
\hline 2 & $1.44(0.10)$ & $1.95(0.01)$ & $3.39(0.04)$ & 42.6 & 8.8 & m-sat \\
\hline 3 & $1.23(0.05)$ & $1.74(0.14)$ & $2.97(0.02)$ & 41.3 & 7.7 & $\mathrm{~m}$ \\
\hline 4 & $1.32(0.12)$ & $1.51(0.08)$ & $2.84(0.01)$ & 46.6 & 7.4 & $\mathrm{~m}$ \\
\hline 5 & $1.11(0.10)$ & $1.56(0.03)$ & $2.67(0.04)$ & 41.4 & 6.9 & $\mathrm{~m}$ \\
\hline 6 & $1.11(0.03)$ & $1.47(0.12)$ & $2.57(0.04)$ & 43.0 & 6.7 & $\mathrm{~m}$ \\
\hline 7 & $1.13(0.02)$ & $1.32(0.12)$ & $2.45(0.04)$ & 46.1 & 6.4 & $\mathrm{~m}$ \\
\hline 8 & $1.05(0.09)$ & $1.26(0.06)$ & $2.31(0.01)$ & 45.3 & 6.0 & $\mathrm{~m}$ \\
\hline 9 & $1.02(0.03)$ & $1.19(0.11)$ & $2.21(0.01)$ & 46.2 & 5.7 & $\mathrm{~m}$ \\
\hline 10 & $0.94(0.07)$ & $1.07(0.11)$ & $2.01(0.01)$ & 46.7 & 5.2 & $\mathrm{~m}$ \\
\hline 11 & $0.81(0.06)$ & $0.90(0.04)$ & $1.71(0.01)$ & 47.2 & 4.4 & $\mathrm{~m}$ \\
\hline 12 & $0.72(0.03)$ & $0.93(0.04)$ & $1.65(0.04)$ & 43.8 & 4.3 & $\mathrm{~m}$ \\
\hline 13 & $0.69(0.01)$ & $0.79(0.02)$ & $1.48(0.01)$ & 46.3 & 3.8 & $\mathrm{~m}$ \\
\hline 14 & $0.85(0.04)$ & $1.60(0.04)$ & $2.45(0.01)$ & 34.8 & 6.4 & $\mathrm{sm}$ \\
\hline 15 & $0.67(0.01)$ & $1.45(0.01)$ & $2.13(0.03)$ & 31.6 & 5.5 & sm \\
\hline 16 & $0.66(0.08)$ & $1.18(0.10)$ & $1.84(0.02)$ & 35.9 & 4.8 & sm \\
\hline \multicolumn{7}{|c|}{ Cyclopogon oliganthus } \\
\hline 1 & $1.13(0.04)$ & $1.25(0.04)$ & $2.38(0.09)$ & 47.4 & 6.0 & $\mathrm{~m}$ \\
\hline 2 & $1.06(0.01)$ & $1.19(0.01)$ & $2.25(0.01)$ & 47.2 & 5.7 & $\mathrm{~m}$ \\
\hline 3 & $1.03(0.02)$ & $1.22(0.02)$ & $2.25(0.01)$ & 45.8 & 5.7 & $\mathrm{~m}$ \\
\hline 4 & $1.03(0.02)$ & $1.19(0.01)$ & $2.22(0.02)$ & 46.5 & 5.6 & $\mathrm{~m}$ \\
\hline 5 & $0.97(0.02)$ & $1.22(0.02)$ & $2.19(0.01)$ & 44.3 & 5.6 & $\mathrm{~m}$ \\
\hline 6 & $0.94(0.04)$ & $1.22(0.02)$ & $2.16(0.01)$ & 43.5 & 5.5 & $\mathrm{~m}$ \\
\hline 7 & $0.97(0.02)$ & $1.13(0.04)$ & $2.09(0.02)$ & 46.3 & 5.3 & $\mathrm{~m}$ \\
\hline 8 & $0.97(0.02)$ & $1.06(0.01)$ & $2.03(0.02)$ & 47.7 & 5.2 & $\mathrm{~m}$ \\
\hline 9 & $0.91(0.02)$ & $1.09(0.02)$ & $2.00(0.02)$ & 45.3 & 5.1 & $\mathrm{~m}$ \\
\hline 10 & $0.94(0.01)$ & $1.06(0.01)$ & $2.00(0.01)$ & 46.9 & 5.1 & $\mathrm{~m}$ \\
\hline 11 & $0.91(0.02)$ & $1.09(0.02)$ & $2.00(0.01)$ & 45.3 & 5.1 & $\mathrm{~m}$ \\
\hline 12 & $0.91(0.02)$ & $1.03(0.02)$ & $1.94(0.01)$ & 46.8 & 4.9 & $\mathrm{~m}$ \\
\hline 13 & $0.88(0.04)$ & $1.03(0.02)$ & $1.91(0.02)$ & 45.9 & 4.9 & $\mathrm{~m}$ \\
\hline 14 & $0.88(0.01)$ & $1.00(0.01)$ & $1.88(0.01)$ & 46.7 & 4.8 & $\mathrm{~m}$ \\
\hline 15 & $0.88(0.01)$ & $1.00(0.01)$ & $1.88(0.01)$ & 46.7 & 4.8 & $\mathrm{~m}$ \\
\hline 16 & $0.84(0.02)$ & $0.94(0.01)$ & $1.78(0.02)$ & 47.4 & 4.5 & $\mathrm{~m}$ \\
\hline 17 & $0.75(0.01)$ & $1.00(0.01)$ & $1.75(0.01)$ & 42.9 & 4.5 & $\mathrm{~m}$ \\
\hline 18 & $0.77(0.01)$ & $0.95(0.03)$ & $1.72(0.02)$ & 44.5 & 4.4 & $\mathrm{~m}$ \\
\hline 19 & $0.69(0.01)$ & $0.81(0.01)$ & $1.50(0.01)$ & 45.8 & 3.8 & $\mathrm{~m}$ \\
\hline 20 & $0.59(0.02)$ & $0.78(0.07)$ & $1.38(0.09)$ & 43.2 & 3.5 & $\mathrm{~m}$ \\
\hline 21 & $0.75(0.01)$ & $1.63(0.04)$ & $2.38(0.04)$ & 31.6 & 9.9 & $\mathrm{sm}$ \\
\hline 22 & $0.75(0.01)$ & $1.50(0.01)$ & $2.25(0.01)$ & 33.3 & 9.4 & $\mathrm{sm}$ \\
\hline 23 & $0.75(0.01)$ & $1.50(0.01)$ & $2.25(0.01)$ & 33.3 & 9.4 & $\mathrm{sm}$ \\
\hline 24 & $0.75(0.01)$ & $1.44(0.01)$ & $2.19(0.01)$ & 34.3 & 9.1 & $\mathrm{sm}$ \\
\hline 25 & $0.69(0.04)$ & $1.47(0.02)$ & $2.16(0.02)$ & 31.9 & 9.0 & $\mathrm{sm}$ \\
\hline 26 & $0.72(0.04)$ & $1.34(0.02)$ & $2.06(0.04)$ & 34.8 & 8.6 & $\mathrm{sm}$ \\
\hline 27 & $0.66(0.02)$ & $1.25(0.01)$ & $1.91(0.02)$ & 34.4 & 7.9 & $\mathrm{sm}$ \\
\hline 28 & $0.63(0.01)$ & $1.25(0.01)$ & $1.88(0.01)$ & 33.3 & 7.8 & sm \\
\hline 29 & $0.63(0.01)$ & $1.19(0.01)$ & $1.81(0.01)$ & 34.5 & 7.5 & $\mathrm{sm}$ \\
\hline 30 & $0.63(0.01)$ & $1.13(0.01)$ & $1.75(0.01)$ & 35.7 & 7.3 & sm \\
\hline 31 & $0.63(0.01)$ & $1.13(0.01)$ & $1.75(0.01)$ & 35.7 & 7.3 & $\mathrm{sm}$ \\
\hline 32 & $0.63(0.01)$ & $1.06(0.01)$ & $1.69(0.01)$ & 37.0 & 7.0 & $\mathrm{sm}$ \\
\hline
\end{tabular}

$s$, mean short arm length; $l$, mean long arm length; $c$, mean chromosome length; $i$, centromeric index; RL\%, relative chromosome length; SE, standard error 